\title{
Review
}

\section{Effect of Abiotic Stress on Onion Yield: A Review}

\author{
Vassanthini R. Ratnarajah ${ }^{\mathrm{a},{ }^{*}}$ and Niroash G. Gnanachelvam ${ }^{\mathrm{a}}$ \\ a Department of Biosystems Technology, Faculty of Technology, Eastern University, \\ Batticaloa 30000, Sri Lanka \\ Email correspondence: vassanthini93@gmail.com (Vassanthini R. Ratnarajah)
}

Received: 29 March 2021; Revised: 20 April 2021; Accepted: 1 May 2021; Published: 31 May 2021

\begin{abstract}
Onion (Allium cepa L.) is a spice crop and a valuable economic crop cultivated in a variety of environments around the world. Because of its export demand, it is extremely important in terms of foreign exchange. Drought stress, waterlogging stress, heat stress, cold stress, and salinity stress all have an impact on onion growth, production, and yield in different ways. A lack of water causes low productivity, therefore to increase onion yield, a constant supply of water is needed. Onions are particularly susceptible to salt stress. The number of bulbs per unit area, height, and fresh weight of onion bulbs, are all affected by salinity in irrigation water. It has an effect on bulbing and the quality of harvested bulbs. Waterlogging has a major effect on bulb development and yield at various growth stages. Waterlogging stress in onions may prevent moving from source to sink, lowering bulb yield. The possible flavor of onions can be affected by the surrounding climate. The bulbing response is influenced by temperature, and the degree to which it is influenced varies by variety. As the temperature increases, the number of leaves decreases. The bulb diameter, bulb weight, and bulbing index (bulb/neck diameter) all increase as the temperature rises. This review provides an in-depth description of the effect of abiotic stress on onion yield.
\end{abstract}

Keywords: Onion, heat stress, salinity stress, drought stress, yield 


\section{Introduction}

The onion (Allium cepa L.), a member of the Alliaceae family, is a spice crop grown in a variety of environments around the world. It is an important economic crop because of its export demand, thus plays a vital role in foreign exchange. It is cultivated in a 5,039,908-ha land area worldwide with a world production of about $96,773,819$ tonnes for the year 2018 [1]. Onion bulbs are cultivated in both tropical and temperate regions and are consumed throughout the year with high consumer preference because of their distinctive sensory and beneficial compounds [2].

Onions can be grown successfully in most fertile soils. A pH of 6-7 is normally recommended for soil. On organic soils, however, a lower $\mathrm{pH}$ is appropriate. In Sri Lanka's dry zone, suitable soil types (Reddish Brown Earth and Regosols) are present. Since it is a long-day plant, the crop needs a longer day duration (> 12 hours). However, some varieties that can be grown in the tropics require a day length of 11-12 hours. Only this sort of variety can produce good bulbs during the Yala season in Sri Lanka. Throughout the crop cycle, there should be less rain (less than $750 \mathrm{~mm}$ ). RH of less than $70 \%$ is considered satisfactory [3]. According to Pitrat [4], onions are thought to have originated in Central Asia, with the Mediterranean region serving as a secondary center of origin for onions with large bulbs [5]. With the world's population rising at an exponential rate, market demand for onions is increasing. However, abiotic stresses such as drought stress, waterlogging stress, heat stress, cold stress and salinity stress play an adverse impact on the growth, development and yield of onion around the globe. Thus, it is important to know the adverse impacts caused by the environment on the production of onions.

\section{Impact of Abiotic Stresses}

Abiotic stresses are now one of the major constraints to global crop development. A considerable portion of the population in developing countries where subsistence agriculture still exists is constantly 
threatened by abiotic stress factors and their interactions with biotic stress factors. As a result of climate change, the situation is likely to get worse. With the predicted increment in global population and food demand, it will be critical to find ways to boost crop tolerance to abiotic stress factors to improve agricultural production and food security [6]. Drought, waterlogging, heat, cold and salinity stresses and their adverse role in onion production are discussed here.

\section{Drought Stress}

Onion is an irrigated crop, which consumes an ample amount of irrigation water for its productions. Poor water availability results in low productivity. High soil moisture is required for onions to produce a high yield [7]. Onions are considered a shallow-rooted crop, mostly penetration is up to $18 \mathrm{~cm}$ and very few roots are extended up to $31 \mathrm{~cm}$ [8], therefore it extracts very little water from depths beyond $60 \mathrm{~cm}$. Srinivasa Rao [9] stated that most of the soil water is absorbed from the top $30 \mathrm{~cm}$, therefore, it is important to keep the soil moist to provide enough water for the plant. Srinivasa Rao [10] discovered that when drought stress was applied for 1, 2,3, and 4 weeks in two onion cultivars, Arka Kalyan and Agrifound Dark Red (ADR), the soil moisture gradually decreased. It was $22.0 \%$ at 0 th day, $13.0 \%$ at 1 -week stress, $9.5 \%$ at 2 weeks stress, $6.5 \%$ at 3 weeks stress and $5.5 \%$ at 4 weeks stress. It leads to a significant decrease in bulb fresh and dry mass and bulb yield. Bulb dry matter was reduced by $44.4-54.0 \%$ after 3 weeks of stress.

Continuous supply of water in a required amount increases the yield of onion. Drip irrigation is the best method to provide irrigation under drought-prone areas. Drip irrigation at shorter intervals increased the bulb yield significantly, Bagali et al. [11] found that significantly higher bulb yield ( $\left.46.93 \mathrm{t} \mathrm{ha}^{-1}\right)$ was produced under irrigation schedule at 1-day interval followed by 3 days (42.80 $\mathrm{t} \mathrm{ha}^{-1}$ ) and 2 days interval (46.47 $\mathrm{t}$ ha${ }^{1}$ ). A subsurface drip irrigation experiment was conducted by Ensico et al. [12]. The results showed that the soil moisture affected the yield 
obtained and the size of the onions. Although, the soil moisture level and irrigation scheduling weren't a big concern for the pyruvic acid content, which results in the pungency and the concentration of soluble solids. The soil moisture above $30 \mathrm{kPa}$ at $20 \mathrm{~cm}$ depth yielded high, and the size of the onions was bigger.

Different growth stages of onions that are subjected to soil-drought stress have a great impact on the yield and quality of bulbs. Withholding irrigation at four growth stages, original, production, mid-season, and late-season, as well as a non-stressed treatment as a control, it was found that onions produce the highest average yield of $15.30 \mathrm{Mg} / \mathrm{fed}$, while soil water stress applied at the later stage of onions produced a lower yield of $11.12 \mathrm{Mg} / \mathrm{fed}$. Drought stress also impacts the weight and size of onion bulbs. Non-stressed and water-stressed plants at the initial stage produced the highest average bulb weight of $102 \mathrm{~g}$ and $91 \mathrm{~g}$, respectively and the results differ significantly at 0.05 level of probability [13].

\section{Salinity Stress}

It is expected that by the year $2050,50 \%$ of the cultivated land is affected by severe salinization [14]. Salinity, caused by high $\mathrm{NaCl}$ concentration is one of the major abiotic stresses which limits crop productivity and leads to economic loss [15]. According to the United States Department of Agriculture (USDA), onions are the most sensitive to Salinity compared to other vegetables. Soil salinity affects the growth and photosynthetic metabolism of onions [16].

Salt stress reduces plant growth and yield in several ways. Osmotic stress and ionic toxicity are two main effects of salt stress on crops. The osmotic pressure under the salinity stress in the soil solution exceeds the osmotic pressure in plant cells due to the presence of more salt and thus limits the ability of plants to absorb water and minerals like $\mathrm{K}^{+}$and $\mathrm{Ca}^{2+}$. The side effects caused by the primary effects of salinity stress are; assimilate production, reduced cell expansion and membrane function, and reduced cytosolic metabolism [17]. High salinity causes water deficit around the rhizosphere and results in a high salt concentration, 
in terms of high $\mathrm{Na}^{+}$and $\mathrm{Cl}^{-}$ions [18]. This phenomenon is lethal for plants [19]. Onions are salt and sulfate-sensitive [20].

Salinity in irrigation water has significant impact on the number of bulbs per unit area, size, and fresh weight of onion bulbs. It influences the bulbing and quality of harvested bulbs. Also, salinity at various growth stages of onion affects the fresh weight of bulbs at harvest [21]. Rafika Sta-Baba et al. [21] further stated that the commercial production of onions with salt water requires a delay in the application of salt water after the appearance of the fourth leaf, with an ECw of $1.41 \mathrm{dS} . \mathrm{m}^{-1}$. But this technique is not economical for large-scale production as the yield decrease is $50 \%$. However, it may be applicable for small-scale production systems. The results from the research done by Camilia et al. [22] have shown that irrigating onions with saltwater slows plant growth and biomass production when compared to tap water irrigation. The saltwater concentrations were higher when compared to tap water (300 ppm). Salinity also affects the flavor development and mineral content of onion bulbs. A study conducted on the onion, 'Granex 33' variety against $6 \mathrm{NaCl}$ concentrations showed that increasing $\mathrm{NaCl}$ concentrations results in decreased bulb fresh weight of mature plants, and plants did not even survive at $125 \mathrm{mM} \mathrm{NaCl}$ concentrations. High $\mathrm{NaCl}$ content also decreases the $\mathrm{S}$ content of bulbs, as well as increases the bulb pungency. Even though the soluble solid content of bulbs is not affected. Onions can survive at $\mathrm{NaCl}$ concentrations up to $100 \mathrm{mM}$, and they can avert onion production under similar saline conditions even at moderate $\mathrm{NaCl}$ levels. However, the possibility of using $\mathrm{NaCl}$ at certain developmental stages to affect flavor accumulation and growth has not yet been determined [23]. Application of $\mathrm{H}_{2} \mathrm{O}_{2}$ is reducing the effect of salinity stress in onion by increasing the photosynthetic efficiency [24].

\section{Waterlogging Stress}

Waterlogging is a major abiotic stress that affects crops. It is caused by excessive unpredictable rainfalls and poor soil drainage caused by compacted soils by the use of heavy agricultural machinery [25]. 
Waterlogging affects plant growth, development and yield by declining the oxygen supplied to the submerged tissues [26]. Onion is extremely sensitive to waterlogging stress because of its shallow rooting nature [8]. The extent of damage by waterlogging depends on the season, variety, soil property, crop growth stage, rainfall duration and intensity. These factors are responsible for the bulb yield and survival of plants. Bulb yield affected by waterlogging stress differs from different onion genotypes. The response of onion genotypes to waterlogging stress was studied in a pot experiment [27]. The highest bulb yield at waterlogging stress was observed in W344 genotypes and the lowest was observed in Acc.1630 (Table 1).

Table 1. Effect of waterlogging stress on single bulb weight (g/plant) in onion genotypes at harvesting stage [27].

\begin{tabular}{lc}
\hline Genotypes & Bulb yield (g/plant) \\
\hline W 344 & 8.38 \\
Bhima Dark Red & 7.22 \\
Acc. 1630 & 2.18 \\
W 355 & 4.23 \\
\hline
\end{tabular}

Waterlogging stress can inhibit the translocation of assimilates from source to sink, which reduces the bulb yield [28]. Waterlogging at different growth stages has a significant impact on bulb production and yield. Ghodke et al. [29] stated that waterlogging at early growth stages after transplanting and bulb initiation stage reduces the bulb quality and marketable bulb size. Waterlogging at 1-10 DAT (Days After Transplanting) produced large bulbs (84.6g) followed by 10-20 DAT (65.0g). Waterlogging from 20-90 DAT periods resulted in a sharp reduction in bulb weight. However, in contrast, waterlogging at the bulb maturity stage has a less negative effect on the bulb size (90-100 DAT and 100-110 DAT) (Table 2). 
Yiu et al [30] found that effect of waterlogging was minimized by the pretreatment of Welsh onion with spermidine or spermine. It provides flooding tolerance, most likely by inducing osmoticants and retaining membrane stability. He further stated that application of 2 ppm paclobutrazol (PBZ) to plants protected the Welsh onion from flooding stress.

Table 2. Effect of waterlogging stress (10 days) at specific growth stage on bulb size of onion [29].

\begin{tabular}{cc}
\hline Treatments & Bulb weight $(\mathrm{g})$ \\
\hline Control & 100.4 \\
$\mathrm{~T} 1$ & 84.6 \\
$\mathrm{~T} 2$ & 65.0 \\
$\mathrm{~T} 3$ & 21.1 \\
$\mathrm{~T} 4$ & 31.1 \\
$\mathrm{~T} 5$ & 21.4 \\
$\mathrm{~T} 6$ & 24.3 \\
$\mathrm{~T} 7$ & 32.9 \\
$\mathrm{~T} 8$ & 28.5 \\
$\mathrm{~T} 9$ & 38.3 \\
$\mathrm{~T} 10$ & 72.3 \\
$\mathrm{~T} 11$ & 76.2 \\
$\mathrm{CD}(5 \%)$ & 5.077 \\
\hline
\end{tabular}

T1; 1-10 DAT (Days After Transplanting), T2; 10-20 DAT, T3; 20-30 DAT, T4; 30-40 DAT, T5; 40-50 DAT; T6; 50-60 DAT, T7; 60-70 DAT, T8; 70-80 DAT, T9; 80-90 DAT, T10; 90-100 DAT; T11; 100-110 DAT, Control; Normal irrigation schedule.

\section{Heat Stress}

Rising temperatures around the world, affecting not only plant growth but especially crop productivity, is now a major concern. Hightemperature stress is described by the intensity, duration, and rate of temperature rise. As the temperature rises above a certain threshold, the magnitude and extent of stress rise rapidly, resulting in complex 
acclimation effects that depend on temperature and other environmental factors [31, 32]. When the plant is under heat stress, the seed germination rate is reduced, resulting in reduced photosynthetic efficiency and performance. Pollen viability, fertilization, and grain or fruit formation can all be affected by excessively high temperatures during the reproductive stage. [33,34]. Heat-related damage to reproductive tissues in crop varieties is a significant cause of yield loss in agriculture worldwide [35].

Temperature is one of the vital environmental parameters that impact the onion bulb initiation and formation. Under heat stress, during reproductive growth, tapetal cells lose their function and either become dysplastic [17]. The cardinal temperatures for optimal seedling growth and plant growth before bulb initiation and bulb development are 20$25,13-24,15-21$, and $20-25^{\circ} \mathrm{C}$, respectively [36]. Bolting is favored by very low temperatures during the bulb production stage. The crop matures early during the winter season due to a sudden temperature rise, resulting in smaller bulbs. Temperature rise has been directly linked to a decrease in photosynthetic efficiency and, ultimately, crop yield [36]. Temperature also affects bulbing response, and the degree to which it is influenced varies between varieties. Wickramasinghe et al. [37] discovered that at the lowest temperatures tested $\left(17-22^{\circ} \mathrm{C}\right)$, larger bulbs with thick necks were produced. This could be due to structural changes in the bulb at low temperatures. Photoperiod is also important in bulbing. To produce bulbs, plants should be exposed to a minimum photoperiod. Temperature, rather than photoperiod, regulated bulbing of onion cultivars. This is consistent with the findings of Abdalla [38], Robinson [39], and Currah [40], who found that in the tropics, bulbing of onions is influenced more by temperature than by day length. Lee [41] found that the bulb diameter, bulb index, pyruvic acid content and total sugar content were better between the range of 20 and $25^{\circ} \mathrm{C}$, and the onions grown at $25^{\circ} \mathrm{C}$ had an excellent sweet flavor. Further, he stated that bulb weight reduced at $30^{\circ} \mathrm{C}$ due to heat stress. 


\section{Cold Stress}

Cold and freezing stresses are common environmental abiotic stresses affecting plant growth and development. Crops experience periods of extremely low temperatures in many regions of the world [42, 43]. Such exposure of plants to chilling and drought simultaneously hinders plant growth and therefore affects productivity [44, 45]. Cold injury can limit the production of onion bulbs.

Cold stress, which involves chilling $\left(20^{\circ} \mathrm{C}\right)$ and/or freezing $\left(0^{\circ} \mathrm{C}\right)$ temperatures, harms plant growth and production, as well as limits agricultural productivity. Cold stress inhibits plants from expressing their maximum genetic capacity through inhibiting metabolic processes directly and indirectly by cold-induced osmotic, oxidative, and other stresses [45]. Bigger bulbs with thick necks were formed at the lowest $\left(17-22^{\circ} \mathrm{C}\right)$ temperatures measured, according to Wickramasinghe et al. [37], which may be due to changes in bulb structure at low temperatures. Cold stress can cause poor germination, stunted seedlings, chlorosis, reduced leaf expansion and wilting, and may lead to the death of tissue (necrosis). Cold stress also severely affects the reproductive development of plants. Cold stress induces severe membrane damage and this damage is primarily caused by the acute dehydration caused by freezing during cold stress [46].

As a protection mechanism against cold $\left(0-15^{\circ} \mathrm{C}\right)$ and freezing $\left(0^{\circ} \mathrm{C}\right)$ temperatures, plants undergo a series of physiological and biochemical modifications. Even though not all plants can withstand cold and freezing temperatures, many do so by a process known as "cold acclimation" (CA) $[47,48]$. Su et al [49] found that Welsh onion cultivars cultivated in winter suffered stress in low temperature. Lowtemperature exposure for short durations resulted in an improvement in mean bulb weight per plant [50].

\section{Conclusion}

Drought, waterlogging, salinity, extreme heat and cold are critical factors for onion cultivation. Onion is extremely sensitive to both water 
and heat stress. These stresses harm both bulb and seed production. Soil moisture is critical for onion production because it influences physiological parameters and bulb yield. Managing an onion crop with insufficient irrigation water availability, maximizing irrigation water use efficiency, and mitigating the effects of excess moisture are all difficult tasks. Temperature variations can affect the bulbing. High temperatures are a major environmental concern as they limit vital plant functions like seed germination, seedling growth, plant metabolism, yield and bulbing in onion in various agro-ecological zones around the world. Onions are sensitive to salinity and create a significant impact on the bulb yield and quality. Genetic modifications and chemical treatments that are resistant to high temperatures, flooding, drought, and salinity might be used for the mitigation of abiotic stress in onions for the better improvement of yield.

\section{Conflicts of Interest}

The authors declare no conflicts of interest.

\section{References}

[1] Food and Agriculture Organization Faostat. Food and Agriculture Data; Food and Agriculture Organization: Rome, Italy, 2018; Available online: http://www.fao.org/faostat/en/\#data/QC

[2] C. Mota, C. Luciano, A. Dias, M. J. Barroca, R. Guiné, Convective drying of onion: kinetics and nutritional evaluation. Food Bioprod. Process. 2010. 88, 115-123.

[3] DOA, Department of Agriculture, Big Onion, 2021, https://doa.gov.lk/FCRDI/index.php/en/crop/42-big-onion-e_accessed on 25.04.2021

[4] M. Pitrat, Vegetable crops in the Mediterranean Basin with an overview of virus resistance. Adv. Virus Res. 2012. 1, 1-29.

[5] M. A. Vaddoria, Ganesh Kulkarni, Onion. Biodiversity in Horticultural Crops. 2017. 6, 211-225.

[6] P. P. Calanca, Effects of Abiotic Stress in Crop Production. In: M. Ahmed, C. Stockle, (eds) Quantification of Climate Variability, Adaptation and Mitigation for Agricultural Sustainability. Springer, Cham. 2017.

[7] A. Kadayifci, G. I. Tuylu, Y. Ucar, B. Cakmak, Crop water use of onion (Allium cepa L.) in Turkey. Agric. Water Manage. 2005. 72, 59-68. 
[8] W.O. Drinkwater, B. E. Janes, Effects of irrigation and soil water on maturity, yield, and storage of two onion hybrids. Proceedings of the American Society for Horticultural Science. 1955. 66, 267-279.

[9] N. K. Srinivasa Rao, K. S. Shivashankara, R. H. Laxman, Abiotic Stress Physiology of Horticultural Crops. Abiotic stress physiology of horticultural crops. 2016. 1-368.

[10] N. K. Srinivasa Rao, R. H. Laxman, R. M. Bhatt, Extent of impact of flooding and water stress on growth and yield of onion and tomato. In: Aggarwal PK (ed) Annual progress report of ICAR network project impact, adaptation and vulnerability of Indian Agri- culture to climate change 2009-10. 2010. 111-112.

[11] A. N. Bagali, H. B. Agali, M. B. Patil, Guled, R.V. Patil, Effect of scheduling of drip irrigation on growth, yield and water use efficiency of onion (Allium cepa L.). Karnataka J Agric Sci. 2012. 25, 116-119.

[12] J. Enciso, B. Wiedenfeld, J. Jifon, S. Nelson, Onion yield and quality response to two irrigation scheduling strategies. Scientia horticulturae. 2009. 120, 301-305.

[13] A. M. Zayton, Effect of Soil-Water Stress on Onion Yield. Misr J. Ag. Eng. 2007. 24, 141-160.

[14] W. Wang, B. Vinocur, A. Altman, Plant responses to drought, salinity and extreme temperatures: towards genetic engineering for stress tolerance. Planta. 2003. 218, 1-14.

[15] D. A. Capiati, S.M. Pa1s, M.T. Tellez-Inon, J. Exp. Bot. 2006. 57, 2391-2400.

[16] Beinşan, Carmen Sumalan, Radu Vâtcă, Sorin, Influence of Salt Stress on Quality of Some Onion (Allium cepa L.) Local Landraces. Bulletin of University of Agricultural Sciences and Veterinary Medicine Cluj-Napoca. Agriculture. 2015. 72, 4-6.

[17] A. Gull, A. A. Lone, N. U. Wani, Biotic and abiotic stresses in plants. Abiotic and biotic stress in plants. 2019. 7, 1-9.

[18] N. Kunchge, K. Kumar, P. Firke, Vegetable Crops (Chili Pepper and Onion): Approaches to Improve Crop Productivity and Abiotic Stress Tolerance. In Improving Crop Resistance to Abiotic Stress (eds N. Tuteja, S.S. Gill, A.F. Tiburcio and R. Tuteja). 2012.

[19] T. Yamaguchi, E. Blumwald, Trends Plant Sci., 2005. 10, 616-619.

[20] S. Ryang, S. Woo, S. Kwon, S. Kim, S.H. Lee, K. Kim, D. Lee. Changes of net photosynthesis, antioxidant enzyme activities, and antioxidant contents of Liriodendron tulipifera under elevated ozone. Photosynthetica. 2009. 47, 19-25.

[21] R. Sta-Baba, M. Hachicha, M. Mansour, H. Nahdi, M.B. Kheder, Response of onion to salinity. Afr. J. Plant Sci. 2010. 4, 7-12. 
[22] Y. Camilia, El-Dewiny, M. M. Hussein, F. Awad, Influence of mono potassium phosphate fertilizer on mitigate the negative effects of high saline irrigation water on onion crop. Middle East J. Agric. Res. 2013. 2, 152-158.

[23] P. Chang, W. M. Randle, Sodium chloride in nutrient solutions can affect onion growth and flavor development, HortScience HortSci, 2004. 39, 1416-1420.

[24] W.M. Semida, Hydrogen peroxide alleviates salt-stress in two onion (Allium cepa L.) cultivars. American-Eurasian J. Agric. E Environ. Sci. 2016. 16, 294-301.

[25] Y. Hirabayashi, R. Mahendran, S. Koirala, L. Konoshima, D. Yamazaki, S. Watanabe, H. Kim, S. Kanae, Global flood risk under climate change. Nat. Clim. Chang. 2013. 3, 816.

[26] T. C. Barickman, C. R. Simpson, C. E. Sams, Waterlogging Causes Early Modification in the Physiological Performance, Carotenoids, Chlorophylls, Proline, and Soluble Sugars of Cucumber Plants. Plants (Basel). 2019. 8, 160.

[27] S. Dubey, V.B. Kuruwanshi, P.H. Ghodke, V. Mahajan, Biochemical and yield evaluation of onion (Allium cepa L.) genotypes under waterlogging condition. Int. J. Chem. Stud. 2020. 8, 2036-2040.

[28] Y. L. Prasanna, G.R. Rao, Effect of waterlogging on growth and seed yield in greengram genotypes. Int. J. Food Agri. Vet Sci. 2014. 4, 124-128.

[29] P. H. Ghodke, D. V. Shirsat, A. Thangasamy, V. Mahajan, V. N. Salunkhe, Y. Khade, M. Singh, Effect of Water Logging Stress at Specific Growth Stages in Onion Crop. Int.J.Curr.Microbiol.App.Sci. 2018. 7, 3438-3448.

[30] J. C. Yiu, C. W. Liu, D. Y. Fang, Y. S. Lai, Waterlogging tolerance of Welsh onion (Allium fistulosum L.) enhanced by exogenous spermidine and spermine. Plant Physiol. Biochem. 2009. 47, 710-6.

[31] G. A. Slafer, H. M. Rawson, Base and optimum temperatures vary with genotype and stage of development in wheat. Plant Cell Environ. 1995. 18,671-679.

[32] B. Wollenweber, J. R. Porter, J. Schellberg, Lack of interaction between extreme high- temperature events at vegetative and reproductive growth stages in wheat. J Agron Crop Sci. 2003. 189, 142-150.

[33] J. L. Hatfield, K. J. Boote, P. Fay, L. Hahn, R.C. Izaurralde, B. A. Kimball, T. Mader, J. Morgan, D. Ort, W. Polley, A. Thomson, D. Wolfe, Agriculture In: The Effects of Climate Change on Agriculture, Land Resources, Water Resources, and Biodiversity in the United States. 2008.

[34] J. L. Hatfield, K. J. Boote, B. A. Kimball, L. H. Ziska, R. C. Izaurralde, D. Ort, A. M. Thomson, D. W. Wolfe Climate impacts on agriculture: implications for crop production. Agron. J. 2011. 103, 351-370.

[35] N. Suzuki, G. Miller, H. Sejima, J. Harper, R. Mittler, Enhanced seed production 
under prolonged heat stress conditions in Arabidopsis thaliana plants deficient in cytosolic ascorbate peroxidase 2. J Exp Bot. 2013. 64, 253-263.

[36] S. Mathur, S. I. Allakhverdiev, A. Jajoo, Analysis of high temperature stress on the dynamics of antenna size and reducing side heterogeneity of photosystem II in wheat ( Triticum aestivum). Biochim Biophys Acta. 2011. 1807, 22-29.

[37] U. L. Wickramasinghe, C. J. Wright, L. Currah, Bulbing responses of two cultivars of red tropical onions to photoperiod, light integral and temperature under controlled growth conditions. J Hortic Sci Bio-tech. 2000. 75, 304-311.

[38] A. A. Abdalla, Effect of temperature and photoperiod on bulbing of common onion (Allium cepa L.) under arid tropical conditions of the Sudan. Exp Agric. 1967. 3,137-142.

[39] J. C. Robinson, Studies on the performance and growth of various short-day onion varieties (Allium cepa L.) in the Rhodesian Lowveld in relation to sowing. 1. Growth analysis. Rhod J Agric Res. 1973. 11, 51-68.

[40] L. Currah, Review of three onion improvement schemes in the tropics. Trop Agric. 1985. 62,131-136.

[41] E. Lee, J. K. Suh, Effect of Temperature on the Growth, Pyruvic Acid and Sugar Contents in Onion Bulbs. Korean J Hortic Sci Technol. 2009, 27, 554-559.

[42] E. Ruelland, M. N. Vaultier, A. Zachowski, V. Hurry, Cold signalling and cold acclimation in plants. Adv. Bot. Res. 2009. 49, 35-150.

[43] W. Wang, Q. Chen, S. Hussain, J. Mei, H. Dong, S. Peng, J. Huang, K. Cui, L. Nie, Pre-sowing seed treatments in direct-seeded early rice: consequences for emergence, seedling growth and associated metabolic events under chilling stress. Sci. Rep. 2016. 6, 19637. 10.1038/srep19637

[44] L. Tommasini, J. T. Svensson, E. M. Rodriguez, A. Wahid, M. Malatrasi, K. Kato, S. Wanamaker, J. Resnik, T. J. Close, Dehydrin gene expression provides an indicator of low temperature and drought stress: transcriptome-based analysis of Barley (Hordeum vulgare L.). Funct. Integr. Genomics. 2008. 8, 387-405.

[45] V. Chinnusamy, J. Zhu, J. K. Zhu, Cold stress regulation of gene expression in plants. Trends in Plant Science, 2007. 12(10), 444-451.

[46] S. K. Yadav. Cold stress tolerance mechanisms in plants. A review. Agron. Sustain. Dev. 2010. 30 (3), 515-527.

[47] C. L. Guy, Cold-Acclimation and Freezing Stress Tolerance-Role of Protein Metabolism. Annu Rev Plant Physiol Plant Mol Biol. 1990. 41, 187-223.

[48] M. F. Thomashow, Plant Cold Acclimation: Freezing Tolerance Genes and Regulatory Mechanisms. Annu Rev Plant Physiol Plant Mol Biol. 1999. 50, 571-99 
[49] H. Su, K.Xu, W. Liu. Cold Tolerance and Winter Cultivation of Welsh Onions. Acta Hortic. 2007, 760: 335-340.

[50] K.M. Khokhara, P. Hadleyb, S. Pearson. Effect of cold temperature durations of onion sets in store on the incidence of bolting, bulbing and seed yield. Sci. Hortic 2007, 112: 16-22. 
